\title{
Entrepreneurs: Strategic Thinkers In Search Of Opportunities
}

Falih M. Alsaaty, (Email: falsaaty@bowiestate.edu), Bowie State University

\begin{abstract}
The purpose of this paper is to explore a perspective concerning the creation of new business ventures, in which the emphasis is on entrepreneurs' strategic thinking skills as well as their perceptions of market opportunities. The paper postulates that strategic thinking is typically the triggering mechanism for decisions to found new ventures. A host of factors constitute the ingredients for the strategic thinking process that lead to decisions.
\end{abstract}

\section{INTRODUCTION}

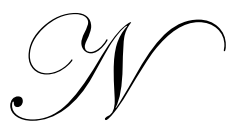

ewly established business ventures are the culmination of a confluence of forces; some are internal to the individual entrepreneurs themselves, while others reside in the external environment. Ventures are born in different sectors of the economy, endowed with unequal amount of resources, and exhibit diverse capabilities. They are founded for different reasons, and created by different kinds of people. In spite of all the differences, there is a common thread especially among successful individuals who establish them, that is, these entrepreneurs are strategic thinkers in search of market opportunities. Many variables account for entrepreneurial success and excellence. As de Bono (1984) indicates, entrepreneurs' ability to spot an opportunity is one direct route to success. As are natural talents, luck, as well as the ability to negotiate deals. Strategic thinking, one may add, is still another contributing factor to success.

The central theme of this paper is that strategic thinking is typically the triggering mechanism influencing the decision making process of individuals to perceive, identify, undertake, and grow new business ventures. Yet, strategic thinking has rarely been discussed in entrepreneurship literature as an essential perspective for new venture creation. It is hoped that the views expressed here might stimulate the interest of researchers to delve further into the psychological perspective of entrepreneurship. Further research may yield results in identifying principles for the wouldbe entrepreneurs to guide them in managing new ventures, as well as to help them transform these budding organizations into high-performance firms. Although the influence of entrepreneurs' skills in strategic thinking extends beyond the initial stage of venture creation encompassing other phases during the life of the enterprise, the focus of this paper is on the role of strategic thinking during the early stages of initiating and implementing a business venture.

Strategic thinkers are in every field and walk of life, and are of various educational and social backgrounds. They exist among different age groups and nationalities. In the business world, for example, individuals with strategic thinking skills are to be found in all kinds of organizations, large and small, and at different levels of managerial responsibilities. Contrary to popular perception, strategic thinking is not the exclusive domain of top executives of multinational corporations; rather, it is the province of all individuals with clear vision, common sense, and sound judgment. What differentiates successful entrepreneurs from other strategic thinkers is that entrepreneurs are in constant search for market opportunities and, at the same time, participate in job creation, innovation, and risk taking. Clearly, not all entrepreneurs are equally ambitious or risk takers. Nor are they deemed to be equally successful or visionary.

\section{ENTREPRENEURSHIP AND ENTREPRENEURS}

As a body of knowledge, entrepreneurship is in its early stage of development and, like other social sciences, is open to divergent views and interpretations. A number of scholars trace the genesis of entrepreneurship to economic theory throughout the eighteen century. Salim (2005) indicates that the research publication of Richard Cantillon in 
1730 was the triggering event for the emergence of the field of entrepreneurship. Salim says that Cantillon was the first to place the entrepreneurship function in the field of economics. In the same vein, Formaini (2006) points out that Cantillon was the most famous Physiocrats whose research contribution introduced the concept of the entrepreneur into economic analysis. Over the years, the list of prominent contributors has become longer, and includes such legends as Joseph Schumpeter (1883-1950) and Peter Drucker (1909-2005). Although rooted in economics, entrepreneurship is considered a multidimensional and complex field (Gartner, 1989; Carland, Hoy, \& Carland, 1988) that draws upon such disciplines as psychology, sociology, ecology, business strategy, as well as economics.

Aside from its origin and historical development, entrepreneurship is viewed in this paper as the pursuit of business opportunities, while the term entrepreneurs is defined as those individuals who perceive themselves as pursing such opportunities (Krueger and Brazeal, 1994). It is to be noted that "entrepreneurship" and "entrepreneurs" are invariably linked to business "opportunities". This assertion is widely accepted in entrepreneurship literature. For example, Vesper (1993) indicates that the goal of an entrepreneur is to gain a profitable advantage in the marketplace. Cromie (2000) declares that entrepreneurship is concerned with economic progress through the exploitation of opportunities. Bygrave and Hofer (1991) treat individuals who exploit opportunities through the creation of organizations as entrepreneurs. Finally, Mcmullen and Shepherd (2006) contend that, to be an entrepreneur, the individual must act on the possibility that he/she has identified an opportunity worth perusing. It is also worthwhile to emphasize that strategic thinking is, in general, the linkage mechanism between entrepreneurs and their success in cultivating opportunities.

\section{VENTURE CREATION: REVIEW OF THE LITERATURE}

For the past three decades, the subject of entrepreneurship has come to the forefront in governmental policy deliberations, business community discussions, as well as academic program planning. The growing interest in entrepreneurship in the United States and elsewhere in the world is partly due to the national needs to encourage individuals to become economically active in their communities, and partly due to the mounting pressure of global competition attributed to governments' economic liberalization policies to promote trade, investment, and the transfer of technology. For these and other reasons, scholars' interest in entrepreneurship has been rekindled, and the subject matter has in recent years come to prominence.

As far as the literature on venture creation is concerned, Gartner (1985) indicates that there are four major conceptual constructs to studying entrepreneurship (or new venture creation). First, characteristics of entrepreneurs; second, the organization which the entrepreneur attempts to create; third, the external environment that surrounds the new venture; and fourth, the process by which the new venture is created. As was mentioned earlier, the objective of this paper is to discuss the last component, that is, the role of strategic thinking in the process of venture creation. As is the case with other aspects of entrepreneurship, venture creation has attracted a fair amount of interest in recent years. Shapero and Sokol (1982), for instance, introduce the concept of "entrepreneurial event formation", and indicate that the formation of a new venture is the most obvious entrepreneurial event. The entrepreneurial event, according to the authors, is not a single act or function, but rather it consists of such elements as risk taking, consolidation of resources, and autonomy. Shapero and Sokol believe that the entrepreneurial event formation alters the person's life path, and involves four separate components: first, negative displacement (e.g., loss of a job), being in between phases of life (e.g., recently out of army), and positive pull (e.g., from a mentor); second, the person's perceptions of desirability (e.g., the influence of culture, family); third, the person's perception of feasibility (e.g., the role of financial support, partners), and fourth, the formation of a business enterprise. In brief, Shapero and Sokol suggest that entrepreneurial formations are the result of interacting situational and cultural factors. On the other hand, Bird (1988) points out that "entrepreneurial intentions" set the form and direction of organizations at their inception. She defines entrepreneurial intentions as entrepreneurs' states of mind that direct attention, experience, and action toward a business concept. Bird also believes that entrepreneurs' intentions guide their goal setting, communication, commitment, and other work aspects. Moreover, the author says that "intuitive, holistic, and contextual thinking frames and structures an entrepreneur's intention and action"(p. 443). Krueger and Brazeal (1994) propose what they call a model for "entrepreneurial potential" to explain the process of new venture creation. According to the model, potential entrepreneurs need not have any salient intentions for starting a business; their potential is latent and prior to intention. The authors also indicate that one can have great potential with virtually no corresponding intentions. Krueger and Brazeal point out that entrepreneurs are made, not born. They are made through a perception-driven process that begins with 
forging a potential for entrepreneurship. Like Shapero and Sokol, Krueger and Brazeal acknowledge the impact of cultural and social context on entrepreneurial activity. Moreover, Busenitz and Lou (1996) introduce a model in which the propensity to engage in entrepreneurial activity is a function of cognition. They put forth the assumption that the way a person processes information has a significant impact on the decision to found a new venture.

Instead of emphasizing a single factor to illuminate the activation process of new venture creation, Learned (1992) suggests a three dimensional model, as follows: (1) propensity to found (i.e., a condition in which the individual is more likely to be a candidate to attempt to found a business), (2) intention to found (i.e., the individual encounters a situation in which it causes intentionality), and (3) sense making (i.e., the individual must make sense of the information obtained during the period to found a business). Learned believes that the three dimensions outlined above lead to a decision to found the venture, or to abandon the attempt all together. He also makes an interesting observation, that is, not all individuals have the potential to form an organization; of those who have potential, not all will attempt; of those who attempt, not all will be able to succeed. In another study, Rotefoss and Kolvereid (2005) classify new venture gestation into milestones, concentrating their analysis on three of the most important: (1) becoming an aspiring entrepreneur (i.e., intention to pursue an entrepreneurial career), (2) a nascent entrepreneur (i.e., an attempt to establish a business), and (3) a founder of fledgling new business (i.e., the actual start-up of a new business). Rotefoss and Kolvereid entertain the idea, much as Learned does, that only some individuals who attempt to found a business actually start a new business, while others will not. In yet another study aimed at explaining the reasons for individuals to pursue entrepreneurial opportunities, Lee and Venkataraman (2006) theorize that "when there is disequilibrium between the aspiration vector $(\mathrm{AV})$ of an individual and the perceived valuation of the market offering vector (PMOV), an individual tends to pursue entrepreneurial opportunities" (p. 107). In other words, "individuals whose VA exceeds that offered by available MOV are more likely to pursue entrepreneurial opportunities" (p. 109). Lee and Venkataraman define the aspiration vector to include economic, social, and psychological benefits that an individual would like to gain, while the market offering vector consists also of economic, social, and psychological benefits that are implicitly or explicitly available to the individual from the labor market. Lee and Venkataraman, in a nutshell, view venture creation from the point of view of interaction between an individual's level of aspiration and his/her appraised value in the labor market. Furthermore, Sarason, Dean, and Dillard (2006) view the entrepreneurial process through the structuration theory, in which entrepreneurship is thought of as the nexus of opportunity and agency. The authors believe that "entrepreneurial ventures are created by purposeful actions through a unique co-evolutionary interaction between the entrepreneur and the socio-economic system"(p.294).

Aldrich (1990) analyzes the phenomenon of new venture creation from an ecological standpoint rather than the more traditional perspectives (i.e., psychological, behavioral, economic). He espouses the so-called "rates approach" model, which simply means that environmental conditions generate variations in the number of foundings over the long- run. Aldrich concludes that there are three processes affecting founding rates: intra-population, interpopulation, and institutional. Finally, in a study of venture creation in Singapore, Choo and Wong (2005) conclude that would-be entrepreneurs are motivated to start a business by three sets of factors: (1) intrinsic rewards, (2) autonomy/ independence, and (3) extrinsic rewards. Choo and Wong define intrinsic rewards in terms of psychological factors (e.g., to have an interesting job, to take advantage of one's creative talents), while extrinsic rewards are financial, or tangible, factors (e.g., to earn more money, the need for a job). In conclusion, the different perspectives to new venture creation briefly outlined above have contributed to our knowledge about the triggering factors/events that motivate an entrepreneur to establish a business enterprise. The diversity of approaches that address the subject matter is a reflection of the complexity of the subject, as well as its importance.

\section{STRATEGIC THINKING}

Creating something from nothing - dubbed bricolage - is an act of deliberate thinking. Creating a whole new business venture is an act of strategic thinking. Thinking is the ultimate human resource that involves moving from one state of knowledge to a better one (de Bono, 1982). Thinking also involves memory, plans, ideas, and possibilities (Hayes, 1994). The brain - the human central control as is often called - regulates thinking as well as everything else human beings do. What happens in the brain is information, and the way it happens is thinking (de Bono, 1969). Historically, in publications, thinking has been given various names over the years. In this paper, thinking is classified into two types: vertical thinking and strategic thinking. Vertical thinking is employed here to mean logical thinking, 
mathematical thinking, analytical thinking, and rational thinking. Although each of these thinking modes might be considered a particular method of thinking, their territories are in fact difficult to determine, and their boundaries are illusive and interlinked. Therefore, it could be argued that, in reality, the meanings of these terms are fundamentally similar. As Hussey (2001) points out, there is no rigid sequence to whether bright ideas precede or follow analytical activities. Vertical thinking is sequential, disciplined, and rule-based, and in it the individual moves in the thinking process forward by sequential steps, each of which must be justified (de Bono, 1970).

On the other hand, the term strategic thinking is used in the paper to refer to thinking that is lateral, critical, and creative. These terms are again interlinked, and their meanings are essentially the same. And the choice of the term strategic thinking is more fitting for its richness and clarity. As is the case with vertical thinking, it appears that there is no consensus on a definition for strategic thinking. For example, Liedtka (1998) defines strategic thinking in terms of five attributes: a system of holistic view, a focus on intent, time-based, hypothesis- driven, and intelligently opportunistic. Dixit and Nalebuff (1991, p. 3) define strategic thinking as "the art of outdoing an adversary, knowing that the adversary is trying to do the same to you". Larson and Hansen

(2005, p. 1) define it as "a distinct form of pragmatic reasoning". We, however, view strategic thinking as referring to "sensible ideas, thoughtful analyses, and sound decisions" (Alsaaty, 2006, p. 26). It is no news that strategic thinking is deeply rooted in human history. Cultivation of the land through agricultural activities and domestication of animals, as well as the invention of writing and the wheel are few examples of brilliant ideas and insightful thinking. Strategic thinking is the foundation of civilizations, and the source of economic progress.

As experts reveal, the brain is divided into two hemispheres: The left- hemisphere (performs the vertical thinking as defined above) and the right- hemisphere (performs the strategic thinking as stipulated above). Both brain segments are deemed crucial for proper human functioning, because they complement each other. As Pink (2006) elaborates, although the power of the left-brain is necessary, it is not sufficient; and it must be augmented with the capabilities of the right- brain, if rapid progress is to take place. The position taken in this paper is that successful entrepreneurs are strategic thinkers, that is, they are intensely more inclined to utilize the power of their right- brains than the general population. Furthermore, business minded individuals with strategic thinking skills are likely to become more successful entrepreneurs in the long-run as compared to business minded, mediocre thinking individuals. Undoubtedly, the quality of thinking can be improved through training, practice, and experience.

\section{BENEFITS OF STRATEGIC THINKING TO ENTREPRENEURS}

Strategic thinking is proactive and reflective. It is valuable to all mankind, and especially necessary to those individuals who wish to become successful entrepreneurs. Strategic thinking enables entrepreneurs to navigate with self-assurance in a dynamic, competitive environment. The benefits of this type of thinking skills are well recognized. Barnett and Berland (1999), for instance, indicate that strategic thinking capability can help businesses identify ways to develop confident forecasts, and to reduce the uncertainty of business decisions. Graetz (2002) declares that strategic thinking is seen as central to creating and sustaining competitive advantage. Additionally, strategic thinking can assist entrepreneurs in other areas, including the following:

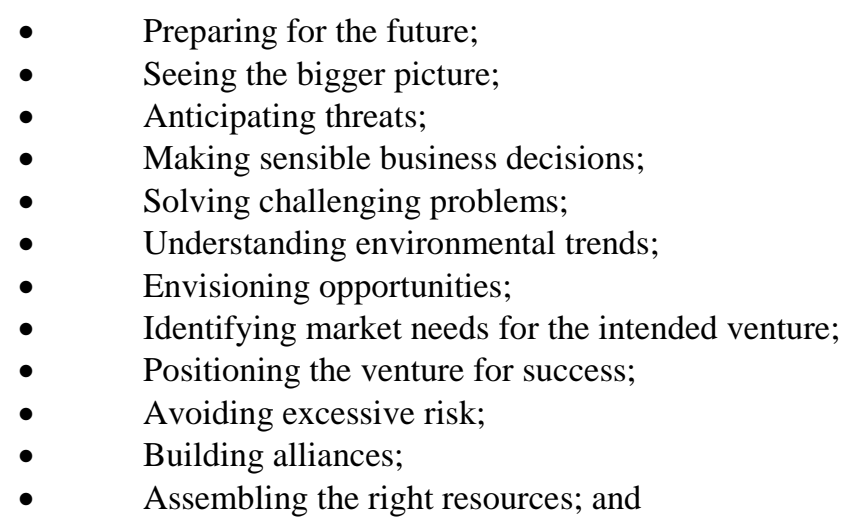


- $\quad$ Managing for results.

The combined effects of these benefits of strategic thinking on entrepreneur's readiness to identify, assess, and undertake a business venture is bound to be considerable. It is the sheer strategic thinking skills that provide the entrepreneur with the necessary justification, and encouragement, for a decision to pursue an opportunity, or otherwise to refrain from the desire to create a new venture.

\section{VENTURE CREATION: A PERSPECTIVE}

Under normal conditions, strategic thinking capability is the key factor influencing profit-oriented individuals to participate in the creation of new business ventures during their life span. This perspective involves three key components, as follows:

- $\quad$ Strategic thinking capability;

- $\quad$ Perceptions of market opportunities; and

- $\quad$ Decision to create a new venture.

The principal input of information for the individual's strategic thinking process, and subsequent decision to engage in the establishment of a new business, is his/her perception of market opportunities which, in turn, is influenced by a host of variables, including economic, psychological, cultural, and social, or what Shapero and Sokol (1982) call the perceptions of desirability and feasibility. Put simply, a new venture is created as a result of an individual's (i.e., potential entrepreneur) strategic thinking skills, which analyze and act upon perceived market opportunities that, in turn, are created by a host of external factors.

A number of observations are in order. First, this paper does not address the issue of venture founding under abnormal circumstances (i.e., state of affairs in which decisions are made by individuals in the absence of strategic thinking). Abnormal situations could take place when, for instance, an individual with sufficient resources experiences a sudden and unexplained urge to become a businessperson, and acts upon the impulse. Second, Learner's (1992) remark that not all newly established business ventures are viable, or have the necessary ingredients for success, is quite convincing. Although an entrepreneur's strategic thinking plays a critical role in the success of a business firm in the long-term, the issue of growth and expansion of the firm beyond the inception stage is outside the scope of the paper. Third, this paper acknowledges that a would-be entrepreneur could face a number of obstacles in an attempt to translate his/her decision into a concrete outcome (i.e., a new venture). However, the perspective under discussion implies that the individual's strategic thinking process has already explored potential difficulties, threats, and problems that might be encounter prior to the decision to establish a venture. Finally, linking strategic thinking skills to the founding of new ventures, and indirectly to promoting local and national economic growth, implies the necessity of training and educating potential entrepreneurs in the skills under discussion.

\section{CONCLUSION}

Strategic thinking has historically been overlooked in entrepreneurship literature, despite its inherent role in the whole spectrum of entrepreneurial activity, especially the creation of new business ventures. This paper attempts to address this gap by introducing a perspective that links venture creation to the strategic thinking skills of profitseeking individuals, who act to exploit market opportunities made possible largely by external forces. Business ventures exist in all sectors of the economy. They are founded by different entrepreneurs, and for a variety of reasons. Environmental conditions pave the way for their emergence, and contribute to their success or failure. Strategic thinking skills, however, remain the triggering mechanism for entrepreneurial decisions to found them. The proposed perspective gives rise to a number of suggestions. First, communities seeking rapid economic growth should participate in funding training and other programs designed to enhance the thinking skills, especially of young individual aspiring to become entrepreneurs. Second, it is imperative for business schools to consider offering courses in strategic thinking in conjunction with, or independent of, strategic management courses. Third, the theory of strategic thinking is in its infancy, and demands further attention for its development, legitimacy, and cultivation.

\section{REFERENCES}


1. Aldrich, Howard E. (1990). Using an Ecological Perspective to Study Organizational Founding Rates. Entrepreneurship: Theory and Practice, (14) 3, 7-24.

2. Alsaaty, Falih M. (2006). Strategic Thinking; The Art of Achieving Organizational Excellence. International Journal of Effective Management, (3) 1, 17-28.

3. Barnett Jr., William F. and Berland, Terrance P. (1999). Strategic Thinking on the front Lines, McKinsey Quarterly, 2, 118-124.

4. Bird, Barbara (1988). Implementing Entrepreneurial Ideas: The Case for Intention. Academy of Management Review, (13) 3, 442-453.

5. Busenitz, Lowell W. and Lou, Chung-Ming (1996). A Cross Cultural Cognitive Model of New Venture Creation. Entrepreneurship: Theory and Practice, (20) 4, 25-39.

6. Bygrave, William D. and Hofer, Charles W. (1991). Theorizing about Entrepreneurship. Entrepreneurship: Theory and Practice, (16), 2, 13-22.

7. Carland, James W., Hoy, Frank, and Carland, Joann C. (1988). Who is an Entrepreneur? Is a Question worth Asking. American Journal of Small Business, (12) 4, 33-39.

8. Choo, Stephen and Wong, Melvin (2005). Entrepreneurial Intention: Triggers and Barriers to New Venture Creation in Singapore. Singapore Management Review, (19) 2, 1-5.

9. Cromie, Stanley (2000). Assessing Entrepreneurial Inclinations: Some Approaches and Empirical Evidence. European Journal of Work and Organizational Psychology, (90) 1, 7-30.

10. de Bono, Edward (1969). The Mechanism of the Mind. New York: Simon \& Schuster.

11. de Bono, Edward (1970). Lateral Thinking. New York: Harper \& Row, Publishers.

12. de Bono, Edward (1982). de Bono Thinking Course. New York: Facts on File Publications.

13. de Bono, Edward (1984). Tactics: The Art and Science of Business. Boston; Little, Brown and Company.

14. Dixit, Avinash K and Nalebuff, Barry J. (1991). Thinking Strategically, New York: W. W. Norton \& Company.

15. Formaini, Robert L. (2006). The Engine of Capitalist Process: Entrepreneurs in Economic Theory, in Robert W. Price, (editor). Entrepreneurship, Dubuque: IA, McGraw-Hill Dushkin, P. 3.

16. Gartner, William B. (1985). A Conceptual Framework for Describing the Phenomenon of New Venture Creation. Academy of Management Review, (10) 4, 696-706.

17. Gartner, William B. (1989). Some Suggestions for Research on Entrepreneurial Trait and Characteristics. Entrepreneurship: Theory and Practice, (14), 1, 27-37.

18. Graetz, Fiona (2002). Strategic Thinking Versus Strategic Planning: Toward Understanding the Complementarities. Management Decision, (40) 5/6, 456-462.

19. Hayes, Nicky (1994). Psychology. United Kingdom: Hodder Education.

20. Hussey, David (2001). Creative Strategic Thinking and the Analytical Process: Critical Factors for Strategic Success. Strategic Choice, (10) 4, 201-213.

21. Krueger Jr., Norris F. and Brazeal, Deborah V (1994). Entrepreneurial Potential and Potential Entrepreneurs. Entrepreneurship: Theory and Practice, (18) 3, 91-104.

22. Larson, Reed and Hansen David (2005). The Development of Strategic Thinking: Learning to Impact Human Systems in a Youth Activism Program. Human Development, (48) 6, 327-349.

23. Learned, Kevin E. (1992). What Happened Before the Organization? A Model of Organization Formation. Entrepreneurship: Theory and Practice, (17) 1, 39-48.

24. Lee, Joo-Heon and Venkataraman, S. (2006). Aspiration, Market Offerings, and the Pursuit of Entrepreneurial Opportunities. Journal of Business Venturing, (21) 1,107-123.

25. Liedtka, Jeanne M. (1998). Linking Strategic Thinking with Strategic Planning. Strategy and leadership, (26) 4, 30-35.

26. Mcmullen, Jeffery S. and Shepherd, Dean A. (2006). Entrepreneurial Action and the Role of Uncertainty in the Theory of Entrepreneurship. Academy of Management Review, (31) 1, 132-152.

27. Pink, Daniel H. (2006). A Whole New Mind. New York: Riverhead Books.

28. Rotefoss, Beate and Kolvereid, Lars (2005). Aspiring, Nascent, and Fledgling Entrepreneurs. Entrepreneurship \& Regional Development, (17) 2, 109-127.

29. Salim, Ruhul A. (2005). Modeling Entrepreneurship in Small-Scale Enterprises. Applied Economics Letters, (12) $1,51-57$. 
30. Sarason, Yolanda, Dean, Tom, and Dillard, Jesse F. (2006). Entrepreneurship as the Nexus of Individual and Opportunity: A Structuration View. Journal of Business Venturing, (21) 3, 286-305.

31. Shapero, Albert and Sokol, Lisa (1982). The Social Dimension of Entrepreneurship. In Kent, Calvin A., Sexton, Donald L. and Vesper, Karl H. (editors),Encyclopedia of Entrepreneurship, Englewood Cliffs, New Jersey: Prentice- Hall, Inc. pp. 72-90.

32. Vesper, Karl H. (1993). New Venture Mechanism, Englewood Cliffs, New Jersey: Prentice-Hall, Inc.

\section{PROFILE}

Dr. Falih M. Alsaaty is the founder and the coordinator of the MBA Program at the School of Business, Bowie State University, Maryland. He received his MBA and PhD degrees from the Stern School of Business Administration, New York University, New York. Prior to joining Bowie State University Dr. Alsaaty was professor of management and director of international business center at the University of the District of Columbia, Washington, DC. He has extensive teaching and administrative experience, as well as numerous publications in the fields of management, entrepreneurship, and international business.

\section{NOTES}

